\title{
Impacts of culture differences on a brand community - a cross study in sweden, Taiwan and Vietnam
}

- Le Phuoc Luong

- Hua Kieu Phuong Mai

University of Technology, VNU - HCM

(Manuscript Received on July $31^{\text {st }}$, 2013, Manuscript Revised October $04^{\text {th }}$, 2013)

\section{ABSTRACT:}

This study questions the impact of cultural differences on Apple Inc. brand community in three countries: Sweden, Taiwan and Vietnam. On the basis of quantitative and qualitative research, two component factors of brand community are assessed: brand loyalty and psychological attachment to brand community. While the Taiwanese highly evaluate the role of brand loyalty for the formation of brand community and psychological attachment to a brand at moderate level; the Vietnamese consumers highly

Keywords: brand community, culture difference.

\section{INTRODUCTION}

Customers normally form a brand community around a brand. Brand community is a group of loyal consumers of the brand's products or services; thus, a brand can hold the consumers' loyalty through taking care of brand communities. It is possible to state that brand loyalty is an important factor that contributes to the establishment of brand communities. Aside from embracing consumers' loyalty, brand communities can also help to build and improve the consumers' psychological attachments to the communities and the brand [15]. Yet, brand's members can automatically disband brand communities of a brand if the brand loses its status as an icon [10]. In this case, it may also lose their consumers' loyalty and psychological attachment to the brand.

In this study, Apple Inc. brand is the brand chosen as a research subject. Apple Inc. brand has been existed for a long time with many its appreciate both the roles of two factors. In comparison, the Swedish have lowest level assessments. In brief, there are significant differences in the evaluations of these factors of the brand community in cross culture context. Besides, Hofstede's national culture theory is applied as the explanation for the research findings. Last but not least, some implications are given to a brand marketer, especially for Apple Inc's.

communities established around the world. Moreover, it has not been only providing consumers with the best functional products but also myths of Steve Jobs who was its talent cofounder. When using Apple's products, consumers have a strong psychological attachment to the brand since a thirst of being successful in the modern competitive society seems to be satisfied by the myths of Steve Jobs.

Mooij and Hofstede (2010) state that consumers from different cultures react differently to marketing strategies [14]. Hofstede (2012) builds the Hofstede model which identifies five dimensions of cultural differences among countries: power distance (PDI), individualism/collectivism (IDV), masculinity/ femininity (MAS), uncertainty avoidance (UAI), and long-term/short-term orientation (LTO) [9]. The indexes of these five dimensions for Sweden, Taiwan, and Vietnam are shown in the figure 1. 
Figure 1 presents that Taiwan and Vietnam have close scores which are quite different from Sweden in four dimensions: PDI, IDV, MAS, and LTO. This can be explained by the reason that Taiwan and Vietnam are Asian countries while Sweden is a European country. For the index of uncertainty avoidance (UAI), Sweden and Vietnam have the similar scores and lower than
Taiwan. This means, Swedish and Vietnamese are more willing to accept the uncertainties and try new things than Taiwanese. In overall, the three countries have differences in culture for all five dimensions; therefore, this study will use all these indexes, if applicable, to compare the cultural differences among the countries for the topic.

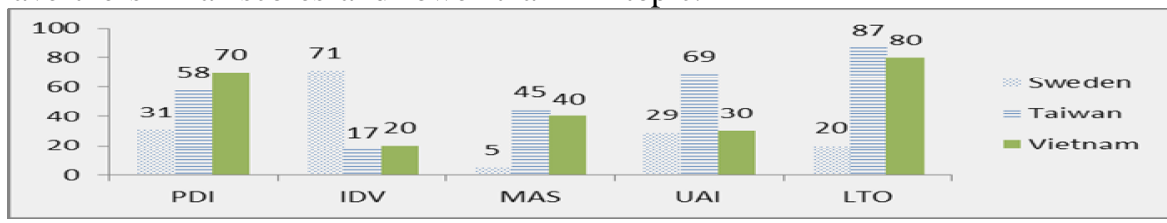

Figure 1: Indexes of five dimensions of cultural differences among Sweden, Taiwan, and Vietnam (Source: Hofstede, 2012, www.geert-hofstede.com)

There is no study found in this topic with the comparison of cultural differences among the three countries: Sweden, Taiwan, and Vietnam. For this reason, the study is conducted with a cross-cultural comparison to identify whether the cultural differences can cause consumers' different assessments of brand community of a brand in three countries: Sweden, Taiwan, and Vietnam.

\section{LITERATURE REVIEW}

\subsection{Brand community}

There are various definitions of a brand community. According to Muniz and O'Guinn (2001), brand community is a special, nongeographically restricted community that builds on a set of social relations based on the admiration of a brand [15]. Bender (1978) states that brand community is a network built on bonds of mutual and emotional relation [4]. McAlexander, Schouten and Koenig (2002) define brand community from a customerexperiential perspective, which is a net of relationships between customers and the brand, customers and the firm, customers and the product in use, and customers and other customers [13]. Arora (2009) generalizes other researchers' opinions and states that brand community is a group of active, investigating, and loyal customers [3].

Brand community is a rather new concept in branding; yet, it has attracted researchers' and managers' attentions for its ability to develop brand loyalty $[3 ; 8]$. Consumers create value through participation in the brand community since this participation holds consumers' loyalty and commitment to the brand $[3 ; 15 ; 17]$. Besides, participating in the brand community can reduce customers' willingness to adopt other brands [19]. Therefore, this study considers brand loyalty is an indispensable factor of brand community. Besides, the psychological attachment to brand community is also proposed to be the componential factors of brand community.

\section{(1) Brand loyalty}

Brand community is a way for a company to enable a strong bond between customers and the brand. This bond can further enhance the brand loyalty [3]. A strong brand community raises consumers' loyalty [6]. According to Aaker (1991), there are six dimensions of brand loyalty $[1 ; 2 ; 7 ; 11]$ : Willingness to purchase, Price premium, Satisfaction rate, Switch cost, Preference over brand, and Commitment to brand.

Willingness to purchase: When a brand is in customers' purchase list and customers have the intention to buy products or services of this brand, there is willingness to purchase. When there is willingness to purchase, the brand has the basis for brand loyalty for that customers are willing to purchase this brand's products or services.

Price premium: The amount of money or effort that customers are willing to pay more for a

\section{Trang 88}


brand compared to other brand is the price premium. The price premium should be compared with a competitor or a group of specific competitors; yet, a group of competitors is a better comparison for that generalization of the product category.

Satisfaction rate: How satisfied customers feel regarding the product or service is satisfaction rate. It is the measurement from customers' view.

Switch cost is also called replacement cost. Switch cost is accounted for the time needed to be familiar with products or services or the monetary cost of switching a supporting system. Besides, there can also be emotional cost of switching. Especially, in iconic brand and brand community, the braking-up of emotional bond should be considered switch cost as well. The emotional lost is consumers' focus here.

Preference over brand is a way to evaluate a brand name which indicates that there is brand loyalty existing. When there is preference over brand, companies can have marginal value that can be extracted from sales or market share.

Commitment to brand: Consumers are emotionally committed to a brand. Brand commitment and preference are often binding together for that they are both emotionally attached to the brand.

These are the degree of consumer's emotional attitudes regarding to the brand [11]. As such, a brand has strong customers' loyalty if it has high assessments from customers for these six elements.

\section{(2)Psychological attachment to brand community}

The core concept of psychological attachment to a brand community is narrowed down to 4 main points [15]:

Consciousness of a kind: Members of a brand community have feelings of being emotionally connected to the brand and even more connected to other members in the community. For the consciousness of a kind, a concept of social and emotional support exists among members of brand community.

Shared rituals and traditions: By sharing rituals and traditions, the meaning of a brand community is created, transmitted, and reached by storytelling. Moreover, sharing brand stories is a crucial process to reinforce the consciousness between brand community and customers.

Desire to contribute to brand's success: McAlexander et al. (2002) state that customers desire to contribute to the brand's success when they are highly integrated and emotionally invested in the brand [13]. Muniz and O'Guinn (2001) describe shortly this concept as a sense of moral responsibility that a consumer may have when being a member of a brand community [15].

Having a sense of moral responsibility: a member's feeling of duty to the community and other members in the community.

\subsection{Cultural aspects of branding}

There has been a question about whether culture affects marketing and branding. Branding is intellectually and emotionally relationships between consumers and brands; it is collective and dynamic (Cayla \& Arnould, 2008) [5]. O'Reilly (2005) states that marketing and brand are cultural related. It is to say, brands socially construct messages that are sent to consumers [16]. In order to succeed in the global market, it is crucial to get the social and cultural meaning of the markets [12]. Culture is also important for consumers to formulate identity and values. Likewise, it is important for the social processes which present how people relate to each other emotionally and subjectively. As shown in the figure 2, branding is affected by individuals' mental process as well as social process both affected by the culture. Thus, branding is under the influence of culture [14] and knowledge about cross culture is essential required for a brand marketer.

There are many models used to explain the cultural effects; yet, the Hofstede's dimensional model of national culture is the most applied one (Mooij \& Hofstede, 2010). The Hofstede culture model points out the five dimensions of cultural differences across countries: power distance, individualism/ collectivism, masculinity/ femininity, uncertainty avoidance, and longterm/short-term orientation [14].

Power distance means how people accept the situation when power is distributed unequally. In 
the high power distance countries, the social hierarchy is important which is suitable for

marketing products that can provide social status need.

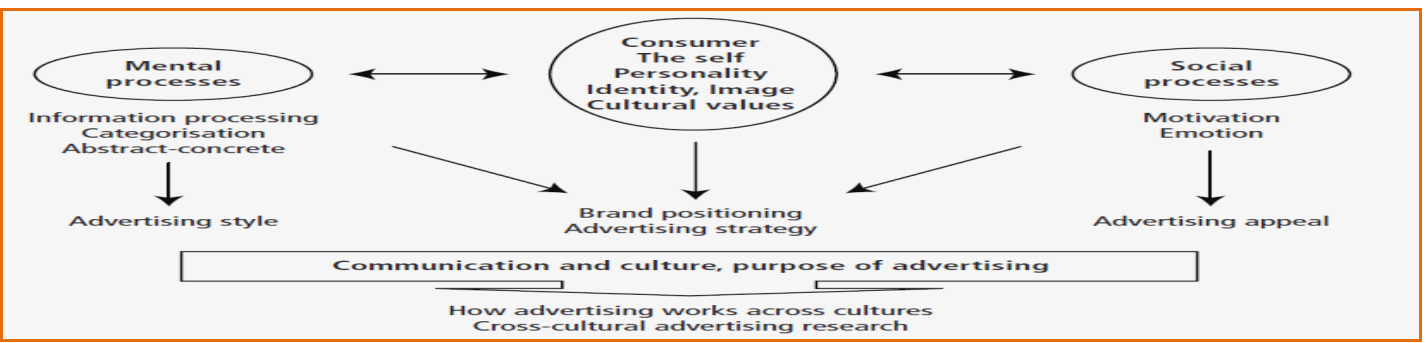

Figure 2: Cross-cultural advertising (Source: Mooij \& Hofstede, 2010)

Individualism/collectivism stands for whether people value individual or group more. In the more individualism culture, "I-conscious" is more cherished while "we-conscious" is important in collectivism culture

In a collectivism culture, the need for being in the group is higher compare to the individualism culture. When in the group, the sense of belongingness and loyalty emerges which can be the case for consumers' need for joining brand community in this study. Also, collective people use less abstract thinking, which leads to preference of concrete product features

In a society, when the dominant value focuses on achievement and success, it is considered masculine. On the opposite, if caring and the quality of life are more cherished, the society is more feminine. In the masculine society, social role is more clarified; for example, men should be out working while women should be at home taking care of children.

Uncertainty avoidance means how people treat uncertainty and ambiguity, which can be explained as the pursuit of truth and belief in professionals. High uncertainty avoidance leads to the reluctant of trying new things and may result low innovation.

The short term orientation focuses on personal steadiness and pursuit for happiness. On the contrary, long term orientation is perseverance and seeks for peace in mind. In the long term orientation, people are willing to invest and expect returns in the future.

Besides, there are many researches prove that people from various cultures act differently. For example, Chinese thinks more relationally and contextually while western people think more analytically [15]. Similar situation happens in collective and/or high power distance societies: people need information that is interpersonal and implicit while in the opposite societies, people acquire information actively through friends and media [16]. In the collective cultures, mostly in Asia, in-group benefits, family, and harmony are attractive [8].

\section{RESEARCH METHODS}

The questions for measurements of brand community are defined clearly and translated into 3 versions for respondents from Sweden, Taiwan, and Vietnam. Brand loyalty is gauged by measurements created on theories of Aaker (1991) while the measurements of psychological attachment to brand community are constructed based on the research of Muniz and O'Guinn (2001). 7-point Likert scales are used for questions asking respondents to score the statements of brand community according to their own ideas. The research respondents are customers of Apple Inc. who owns at least one of Apple Inc.'s products.

After the first version of questionnaires is completed, pilot test is conducted to detect mistakes (whether the data are collectable; if the questionnaire is too short or too long; and if there is any misunderstanding in the questions) before conducting main study. In the pilot test, ten respondents from each country are selected to participate. Some respondents from Sweden mention that specific marketing terminology is not familiar to them. Thus, in order to make the questionnaire efficient, this study defines the main concepts (brand community) in the questionnaire between the section of basic

\section{Trang90}


information and main questions. Besides, since there are 36 questions in the questionnaire, respondents may feel tired and confused. Subtitles, thus, are applied in the questionnaire to guide the respondents about which section they are in. In this case, even if respondents lacked related marketing knowledge, they would still know the main idea of the questions and be able to answer without any misunderstanding. Among respondents in Taiwan and Vietnam, some say that the questions are difficult to understand. Some translation issues are detected and corrected. For example, the grammar is different in English, Chinese, and Vietnamese. Also, the questions are based on American culture mostly, which is very different from Asian cultures. Therefore, some concepts do not exist in Taiwanese and Vietnamese cultures. In-depth discussions are conducted with consumers in Taiwan and Vietnam to refine the wording of questions in each language. The new questions are tested with ten more respondents from each country to guarantee questions clear and understandable.

To collect data, both quantitative and qualitative methods are applied. For the quantitative method, this research uses convenience sampling with self-completion questionnaire. Questionnaires are delivered to the respondents in two ways: sending directly to them by hand and asking them to answer the questionnaires through online survey. Respondents in Taiwan and Vietnam are emailed and messaged on Facebook to click on an Internet address and answer the online survey. These respondents are also asked to send the online survey address to their friends and relatives to finish the online questionnaires. For respondents in Sweden, questionnaires are directly sent to them by hand in public places such as: universities, city libraries, or shopping points where respondents can find seats for reading and answering the questionnaires. After the main survey has been completed, unsuitable questionnaires collected from respondents are discarded, and the sample size is 486 , in which 171 responses $(35.2 \%)$ from Sweden, 163 responses $(33.5 \%)$ from Taiwan, and 152 responses (31.3\%) from Vietnam. Then, quantitative data are coded and analyzed by SPSS.

For the qualitative method, semi-structured interviews with six consumers experiencing with the brand and joining the brand community are conducted. In the self-completion survey method, it is difficult to get additional in-depth data, because the collected data are limited to the specific questions created initially on the survey [18]. Thus, the results of analysis of the quantitative data collected by self-completion questionnaires will be enhanced and discussed indepth by some semi-structured interviews with consumers who have experience with a brand and join the brand community. Interviews with these consumers provide deeper understanding about the quantitative results as well as some additional information that cannot be obtained from the questionnaires. A list of topics and questions are prepared, and then, many others are added due to the flow of the conversations.

\section{DATA ANALYSIS AND RESULTS}

\subsection{Data background}

Figure 3 shows that there are quite equal proportions of respondents in terms of gender. The data have $58.2 \%$ of the total responses from female and $41.8 \%$ of that from male. Although, there is a slight difference in the amounts of responses from male and female, these proportions of gender are acceptable to assure that there is no bias in gender perspectives occurring for this study. The figure also presents that most of respondents are at the ages of 16-25 (43.2\%) and 26-35 (53.3\%). This reflects the fact that people, who pay their attentions to brand community, almost have the ages of the range from 16 to 35 . People, at these ages, are usually dynamic consumers who enthusiastically join a community of their favorite brands. Besides, respondents of this study also belong to the other range of ages, but these proportions of ages are very low (ages from 36-45 account for $2.9 \%$, ages from $46-55$ accounts for $0.4 \%$, and $0.2 \%$ of respondents are at the ages over 55). 


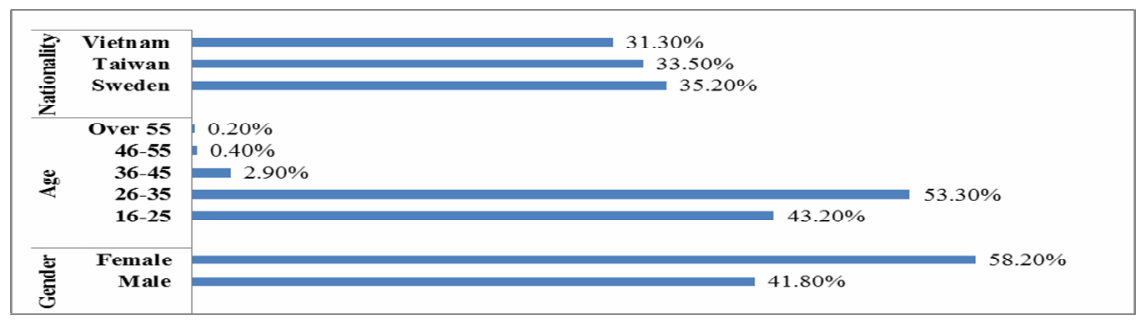

Figure 3: Sample distributions of Nationality, Age, and Gender

\subsection{Exploratory Factor Analysis (EFA) and Cronbach's Alpha Test}

EFA helps to identify the numbers of factors formed from all variables. These variables are divided into 2 factors: brand loyalty and psychological attachment to brand community. With $\mathrm{KMO}=0.922($ sig. $=0.000)$, EFA is suitable applied for the data, and the two factors extracted by the Varimax rotation are appropriate for the further analysis (Eigenvalue $=1.0$; factors loadings $\geq 0.5$ ). Cronbach's Alpha Test also shows the internal reliability of numeric measurements. 10/11 variables (exclude Y5) have accepted Cronbach's Alpha indexes $(\geq 0.6)$ (shown in Table 1).

Table 1: EFA and Cronbach's Alpha indexes

\begin{tabular}{|c|c|c|c|c|}
\hline Factors & Items & Factor 1 & Factor 2 & $\begin{array}{l}\text { Cronbach } \\
\text { Alpha }\end{array}$ \\
\hline \multirow{4}{*}{ Brand loyalty } & Y1: You are willing to buy products/services of this brand. & .650 & & \multirow{4}{*}{0.834} \\
\hline & Y2: You are willing to pay more for the products/services of this brand. & .712 & & \\
\hline & $\begin{array}{l}\text { Y3: You feel satisfied with the past experience regarding the products/services of this } \\
\text { brand. }\end{array}$ & .622 & & \\
\hline & $\begin{array}{l}\text { Y4: You feel emotionally uncomfortable when switching to another brand with same } \\
\text { products/services. }\end{array}$ & .734 & & \\
\hline \multirow{6}{*}{$\begin{array}{l}\text { Psychological } \\
\text { attachment to } \\
\text { brand } \\
\text { community }\end{array}$} & Y6: You feel the sense of belonging to a community of this brand. & & .843 & \multirow[t]{6}{*}{0.922} \\
\hline & Y7: You feel emotionally connected to this brand community. & & .895 & \\
\hline & Y8: You have the feeling that you are socially supported by this brand community. & & .854 & \\
\hline & $\begin{array}{l}\text { Y9: Sharing brand story makes you feel you have common rituals and traditions with } \\
\text { this brand community. }\end{array}$ & & .813 & \\
\hline & $\begin{array}{l}\text { Y10: You are willing to help others (in or out of the brand community) to use the } \\
\text { products/services of this brand. }\end{array}$ & & .780 & \\
\hline & Y11: You have a desire to see the success of this brand. & & .795 & \\
\hline
\end{tabular}

\subsection{Difference in Brand loyalty}

Table 2 presents that Taiwanese and Vietnamese respondents give high scores for most variables of brand loyalty; whereas, Swedish respondents score these four variables at different levels. The Asian respondents highly agree that they are willing to buy products or services of the brand (Y1) and pay more for them (Y2). Moreover, they also have a strong feeling of being satisfied with the past experience regarding the products or services of the brand
(Y3) as well as being emotionally uncomfortable when switching to another brand with same products or services (Y4). Taiwanese respondents give high scores for all four variables while the Vietnamese give high scores for Y1, Y2, Y3 (5.82, 5.54, 5.98 respectively) and the moderate score for Y4 (4.39). Meanwhile, the Swedish respondents give high scores for $\mathrm{Y} 1$ and $\mathrm{Y} 3$ with 5.37 and 5.50 correspondingly, moderate score for Y2 with 4.88, and low score for Y4 with 3.84.

Table 2: Scores of variables of brand loyalty

\begin{tabular}{|l|l|c|c|c|}
\hline \multirow{1}{*}{ Factor } & \multicolumn{1}{|c|}{ Variables } & \multicolumn{2}{c|}{ Scores } \\
\cline { 2 - 5 } \multirow{3}{*}{$\begin{array}{l}\text { Brand } \\
\text { loyalty }\end{array}$} & Y1: You are willing to buy products/services of this brand. & Sweden & Taiwan & \multicolumn{1}{c|}{ Vietnam } \\
\cline { 2 - 5 } & Y2: You are willing to pay more for the products/services of this brand. & 5.37 & 5.77 & 5.82 \\
\cline { 2 - 5 } & $\begin{array}{l}\text { Y3: You feel satisfied with the past experience regarding the products/services of this } \\
\text { brand. }\end{array}$ & 5.88 & 5.17 & 5.54 \\
\cline { 2 - 5 } & $\begin{array}{l}\text { Y4: You feel emotionally uncomfortable when switching to another brand with same } \\
\text { products/services. }\end{array}$ & 3.84 & 5.49 & 5.44 \\
\hline
\end{tabular}

\section{Trang92}




\subsection{Difference in Psychological attachment to brand community}

Table 3 shows that Swedish respondents have moderate feelings of belonging to the community of the brand (Y6 - 4.12), being emotionally connected to brand community (Y7 - 4.28), being socially supported by the brand community (Y8 4.20 ), being willing to help others (in or out of the brand community), to use the products or services of the brand (Y10 - 4.52), and having a desire to see the success of the brand (Y11 4.45). With the statement that sharing brand story can make them have common rituals and traditions with this brand community, they show their low agreement (Y9 - 3.52). Meanwhile, Taiwanese respondents give moderate scores for Y6, Y7, Y8, and Y9 with 4.50, 4.42, 4.25 and 4.29 respectively, and high scores for Y10 and Y11 with 5.47 and 5.26 correspondingly. Vietnamese respondents give high and very high scores for all six variables (Y6, Y7, Y8, Y9, Y10 and Y11 with 5.78, 5.74, 5.55, 5.34, 5.80 and 6.37 respectively).

Table 3: Scores of variables of psychological attachment

\begin{tabular}{|l|l|l|l|l|}
\hline Factor & Variables & \multicolumn{2}{l|}{ Scores } \\
\cline { 3 - 5 } & & Sweden & Taiwan & \multicolumn{1}{l|}{ Vietnam } \\
\hline \multirow{2}{*}{$\begin{array}{l}\text { Psychological } \\
\text { attachment } \\
\text { brand } \\
\text { community }\end{array}$} & Y6: You feel the sense of belonging to a community of this brand. & 4.12 & 4.50 & 5.78 \\
\cline { 2 - 5 } & Y7: You feel emotionally connected to this brand community. & 4.28 & 4.42 \\
\cline { 2 - 5 } & Y8: You feel that you are socially supported by this brand community. & 4.20 & 4.25 & 5.74 \\
\cline { 2 - 6 } & $\begin{array}{l}\text { Y9: Sharing brand story makes you feel you have common rituals and traditions with this } \\
\text { brand community. }\end{array}$ & 3.52 & 4.29 & 5.34 \\
\cline { 2 - 6 } & Y10: You are willing to help others to use the products/services of this brand. & 4.52 & 5.47 & 5.80 \\
\cline { 2 - 6 } & Y11: You have a desire to see the success of this brand. & 4.45 & 5.26 & 6.37 \\
\hline
\end{tabular}

\subsection{Difference in two Brand community's} factors

In short, Swedish respondents assess the brand loyalty and the psychological attachment to a community of a brand at moderate levels (4.64 and 4.18 respectively) while Taiwanese respondents show their high loyalty (5.06) and moderate feeling of psychological attachment to a community of an a brand (4.70). In comparison, Vietnamese respondents give high scores for both brand loyalty (5.63) and psychological attachment (5.76) (shown in Table 4).

Table 4: Scores of brand community's two factors

\begin{tabular}{|c|c|c|c|c|}
\hline \multirow[t]{2}{*}{ Dimension } & \multirow[t]{2}{*}{ Factors } & \multicolumn{3}{|c|}{ Mean } \\
\hline & & Sweden & Taiwan & Vietnam \\
\hline \multirow[t]{2}{*}{ Brand community } & Brand loyalty & 4.64 & 5.06 & 5.63 \\
\hline & Psychological attachment to brand community & 4.18 & 4.70 & 5.76 \\
\hline
\end{tabular}

ANOVA test is applied to find whether there are significant differences in mean values of brand community's factors given by three groups of respondents. All significant levels of ANOVA test (for brand loyalty and psychological attachment to brand community) are smaller than 0.05 (sig. $=0.000$ ) which implies there are significant differences in mean values of these two factors scored by respondents. Table 5 shows the results of ANOVA test for the differences in mean values of two brand community's factors scored by three different groups of respondents: Sweden, Taiwan, and Vietnam.

Table 5: ANOVA test for differences in mean values of brand community's factors

\begin{tabular}{|c|c|c|c|c|c|c|}
\hline \multicolumn{7}{|l|}{ ANOVA } \\
\hline & & Sum of Squares & df & Mean Square & $\mathrm{F}$ & Sig. \\
\hline \multirow[t]{3}{*}{ Brand loyalty } & Between Groups & 79.19 & 2 & 39.59 & 26.73 & .000 \\
\hline & Within Groups & 715.50 & 483 & 1.48 & & \\
\hline & Total & 794.69 & 485 & & & \\
\hline \multirow{3}{*}{$\begin{array}{l}\text { Psychological attachment to } \\
\text { brand community }\end{array}$} & Between Groups & 207.25 & 2 & 103.62 & 71.85 & .000 \\
\hline & Within Groups & 696.54 & 483 & 1.44 & & \\
\hline & Total & 903.80 & 485 & & & \\
\hline
\end{tabular}




\section{DISCUSSION}

The research results show that there are significant differences in assessments of different respondents (from different countries: Sweden, Taiwan, and Vietnam) for the two factors of brand community: brand loyalty and psychological attachment. The results support the previous studies of Cayla and Arnould (2008) and O'Reilly (2005) which state that branding and marketing are culturally and emotionally different. In other words, how consumers perceive a brand is culturally different.

Regarding the perception on brand community's factors, Vietnamese still assess strongest while Taiwanese ranks the middle and Swedish evaluate less. An acceptable explanation is that "Lagom" (Lagom means moderation; not too much, not too little, not too noticeable) makes Swedish people express moderately; hence, the scores on perception is lower in comparison to the other cultures. The perception comparison is presented in Figure 4. Some additional explanations are given by in depth interviews with 6 respondents.

Vietnamese interviewees claim that Vietnamese people have strong need to be in the group; they reflect the emotional attachment to the safety in the group. This is also related to the high power distance and collectivism regarding Hofstede's culture theory. Vietnamese has bigger power distance compared to Taiwan and Sweden; hence, Vietnamese accept the centered power situation which may extend to the centralization of emotional power. In other words, loyalty to the brand indicates that consumers give emotional power up and centered on the brand. Also, loyalty is important in collective culture [9]. Taiwan and Vietnam are collective while Sweden is individual.

Therefore, Taiwanese and Vietnamese perceive more on loyalty in comparison to Swedes. Moreover, Swedes, with lower power distance, need to be independent and accept less control. Being loyal to a brand means less emotional independency and being controlled by the brand emotionally. This leads to the lower perception on loyalty for Swedish people. As for the psychological attachment to the brand community, explanations on the statistical result can be explained by individualism and masculinity theoretically. For collective society, it is crucial to emotionally committed to a group and its members [9]. This reflects on Taiwanese and Vietnamese perceive more on the emotional attachment to the brand community while Swedish culture, as individual one, has less emotional attachment to the brand. As mentioned earlier, all three cultures are feminine. Under the influence of femininity, people are supportive and involve in decision making which harmonizes with the emotional attachment to the brand community: members of the brand community support and are supported by other members. Taiwanese and Vietnamese are both collective and feminine; thus, their scores of this factor are higher than the score of Swedes who are individual and feminine. In practice, Swedish interviewees claim that they pay more attentions to outside activities (such as joining clubs, bars, or travelling with their friends and families); thus, they may not have much time to join online forums of brand communities. Taiwanese interviewees share that they like joining both outside activities and forum activities of brand communities. Whereas, young Vietnamese interviewees state that they may not afford to travel or join clubs or bars. Instead, they prefer to search on Internet for information about products or services that they need. They have feelings of psychological attachment to other members in forums of brand communities. Sharing information to each other in forums is also the way that brings them funs and meaningfulness for their life.

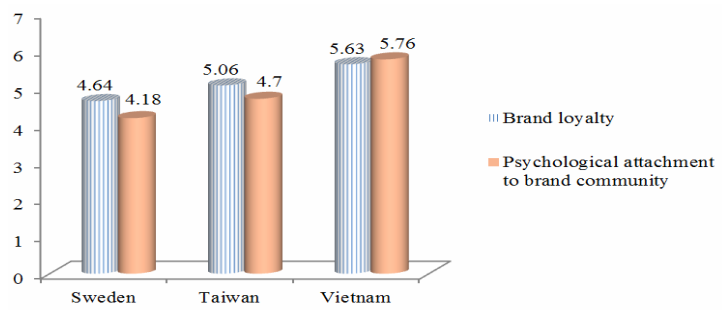

Figure 4: Comparison of brand community's factor scores

\section{CONCLUSION}

For the two factors of brand community, respondents agree with the statement that a brand

\section{Trang94}


community is formed based on consumers' brand loyalty and psychological attachment to brand community at moderate levels. The Taiwanese highly evaluate the role of brand loyalty for the formation of brand community but they think that psychological attachment only has a moderate role in the establishment of a brand community. While Vietnamese consumers highly appreciate the roles of brand loyalty and psychological attachment to brand community, the Swedish have lowest level assessment. In general, there are differences in the evaluations of these factors of brand community given by three kinds of respondents in terms of nationality. Many studies consider brand loyalty as the final achievement of marketing efforts $[1 ; 3 ; 6 ;]$; yet, this study aims at a broader result for attempts of marketing practitioners, especially for Apple Inc. in building brand community. The Apple community does not only embrace the brand loyalty but also include the consumer's psychological attachment to the brand and its community. With respect to the result, it implies that if a brand has it community, it does not only hold the consumers' loyalty to the brand but also create psychological attachment among the consumers as well as to the brand. It also implies in Asian markets (Taiwan and Vietnam) it is very important to build a brand community because it enhances the brand loyalty and psychological attachment to the brand. However, it may not work in Swedish market since a strong brand community cannot assure a high level of brand loyalty and psychological attachment to the brand. Accordingly, further researches should focus more on other factors influencing the brand building, especially in Sweden.

\section{Ảnh hưởng của sự khác biệt văn hóa lên cộng đồng thương hiệu - một nghiên cứu đa văn hóa tại Thụy Điển, Đài Loan và Việt Nam}

- Lê Phước Luông

- Hứa Kiều Phương Mai

Trường Học Bách Khoa, ĐHQG-HCM

\section{TÓM TÁT:}

Nghiên cứu này xem xét tác động của sụ̣ khác biệt văn hóa lên cộng đồng thương hiệu của Apple ở ba quốc gia: Thụy Điển, Đài Loan và Việt Nam. Trên cơ sở nghiên cứu định lượng và định tính, hai yếu tố thành phần của cộng đồng thương hiệu được đánh giá là: lòng trung thành thương hiệu và sự gắn kết cảm xúc đối với cộng đồng thương hiệu. Trong khi, người phản hồi ở Đài Loan đánh giá cao vai trò của lòng trung thành thương hiệu đối với sự hình thành của cộng đồng thương hiệu và sự gắn kết cảm xúc đối với cộng đồng thương hiệu ở mức vừa phải; thì người tiêu dùng Việt Nam đánh giá cao vai trò của cả hai yếu tố. Trong khi đó, người tiêu dùng Thụy Điển có sự đánh giá mức thấp nhất cho cả hai yếu tố này. Tóm lại, có sự khác biệt đáng kể trong việc đánh giá các yếu tố của cộng đồng thương hiệu trong bối cảnh khác biệt văn hóa. Bên cạnh đó, lý thuyết văn hóa quốc gia của Hofstede được áp dụng như lời giải thích cho các kết quả nghiên cứu. Cuối cùng, một số ngụ ý được rút ra cho các nhà tiếp thị thương hiệu, đặc biệt là Apple.

Từ khóa: cộng đồng thương hiệu, khác biệt văn hóa. 


\section{REFERENCES}

[1]. Aaker, A. D. (1991). Managing Brand Equity: Capitalizing on the Value of a Brand Name. New York: Free Press.

[2]. Aaker, A.D. (1996). Measuring Brand Equity across Products and Markets. California Management Review, pp. 102-120.

[3]. Arora, H. (2009). A Conceptual Study of Brand Communities. Journal of Brand Management, pp. 7-21.

[4]. Bender, Thomas. (1978). Community and Social Change in America. New Brunswick: Rutgers University Press.

[5]. Cayla, J., and Arnould, J.E. (2008). A Cultural Approach to Branding in the Global Marketplace. Journal of International Marketing, Vol. 16, No. 4, pp. 86-112.

[6]. Fournier, S., and Lee, L. (2009). Getting Brand Communities Right. Harvard Business Review, pp. 105-111.

[7]. Gerald, R. V. (2009). Panama's Low-Income Consumers' Brand Loyalty: Panamanian Consumers. Boca Raton, Florida: Dissteration.com.

[8]. Han, S.-P., and Shavitt, S. (1994). Persuasion and culture: advertising appeals in individualistic and collectivistic societies. Journal of Experimental Social Psychology, (30), pp. 326-350.

[9]. Heere, B., Walker, M., Yoshida, M., Ko, Y. J., Jordan, J. S., \& James, J. D. (2011). Brand Community Development through Associated Communities: Grounding Community Measurement within Social Identity Theory. Journal of Marketing Theory and Practice, pp. 407-422.

[10]. Hofstede, G. (2012). National culture dimensions. Website: geert-hofstede,http://geerthofstede.com/sweden.html, [2012-04-15].
[11]. Holt, D. B. (2004). How brands become icons: The principal of cultural branding. Harvard Business School Press.

[12]. Jang, H., Olfman, L., Ko, I., Koh, J., and Kim, K. (2008). The Influence of On-Line Brand CommunityCharacteristics on Community Commitment and Brand Loyalty. International Journal of Electronic Commerce, Vol. 12, No. 3, pp. 57-80.

[13]. Javalgi, G. R., Granot, E., and Alejandro, G. B.T. (2011). Qualitative Methods in International Sales Research: Cross-Cultural Considerations. Journal of Personal Selling \& Sales Management, pp.157-17.

[14]. McAlexander, H. J., Schouten, W. J.\& Koenig, F. H. (2002). Building Brand Community.Journal of Marketing, pp. 38-54.

[15]. Monga, B. A., and John, R. D. (2007). Cultural Differences in Brand Extension Evaluation: The Influence of Analytic versus Holistic Thinking. Journal of Consumer Research, pp. 529-536.

[16]. Mooij, M and Hofstede, G. (2010).The Hofstede model, applications to global branding and advertising strategy and research. International Journal of Advertising, 29(1), pp.85-110.

[17]. Muniz, A. M., and O'Guinn, T. C. (2001). Brand Community. Journal of Consumer Research, pp. 412-432.

[18]. O'Reilly, D. (2005). Cultural Brands/ Branding Cultures. Journal of Marketing Management, (21), pp. 573-588.

[19]. Schau, J. H., Muñiz, M., and Arnould, J.E. (2009). How Brand Community Practices Create Value. Journal of Marketing, pp. 30-51.

[20]. Shiu, E., Hair, J., Bush, R. and Ortinau D. (2009). Marketing Research, 1st European edition. UK: McGraw Hill Education.

\section{Trang96}

